\title{
A SEMÂNTICA NOS ESTUDOS DO PORTUGUÊS BRASILEIRO
}

\begin{abstract}
Felipe de Andrade Constancio
Doutorando em Letras pela Universidade do Estado do Rio de Janeiro. Professor de Língua Portuguesa da Secretaria de Estado de Educação do Rio de Janeiro e da Prefeitura Municipal de Volta Redonda.

felipe.letras.ac@gmail.com
\end{abstract}

\section{RESENHA}

BASSO, Renato; ILARI, Rodolfo (org.). História do português brasileiro: história semântica do português brasileiro - volume 8. São Paulo: Contexto, 2020.

Depois de presentear o mercado editorial com a obra $O$ português da gente: $a$ língua que estudamos, a língua que falamos (2006), os autores Rodolfo llari e Renato Basso trazem mais uma contribuição à área da Linguística com a publicação de História semântica do português brasileiro (2020), obra que integra, até o momento, os oito volumes do projeto História do Português Brasileiro, liderado pelo professor Ataliba Teixeira de Castilho.

A obra História semântica está dividida em quatro partes, a saber: "Teoria versus descrição", "Morfologia”, "Gramática" e "Léxico e construções". Partindo da premissa de que a semântica foi considerada por muito tempo "a prima pobre dos estudos linguísticos", Ilari e Basso investem na organização de um volume cuja pretensão descritiva abarca uma área pouco conhecida nos estudos linguísticos, a área da semântica diacrônica.

$\mathrm{Na}$ primeira parte, há dois capítulos. No primeiro deles, Renato Basso faz considerações a respeito da abordagem da Semântica Formal, sem deixar de mencionar as interfaces desta linha teórica com os processos de gramaticalização, relevantes, 
portanto, às incursões funcionalistas. Basso mostra-nos que, por meio de casos de reanálise, existem estruturas que podem (re)ssurgir ou desaparecer no português brasileiro, como no caso de tantos verbos do domínio discursivo da informática.

No segundo capítulo da parte um, Rodolfo llari sinaliza-nos que deve haver um tratamento mais adequado em relação aos corpora para o estabelecimento de um inventário de unidades da língua que ora estão em uso, ora estão em desuso. llari, a partir de sua ampla experiência advinda do manuseio do corpus do português culto escrito, mostra-nos como se configura o trabalho árduo de organização e descrição a partir de documentos históricos.

Na segunda parte, em que se enfoca a morfologia, há um produtivo estudo a respeito do sufixo -aço no português brasileiro. Helio Oliveira, por meio de uma análise diacrônica, recupera o sentido desse sufixo, do latim ao português, de modo a salientar valores semânticos distintos na constituição de palavras em que -aço figura como morfema derivacional.

Ainda na segunda parte, há uma contribuição de Mauricio Resende, que trata de formas cognatas relacionadas à raiz MIT-, como nos exemplos "admitir, emitir, demitir, omitir, permitir, remitir e transmitir". O autor mostra-nos que, em muitos desses casos, o radical assumiu valores distintos do que era veiculado em seu étimo na língua latina, como verbo "mittere".

Na terceira parte, que é dedicada às estruturas gramaticais, Martin Becker investe, em seu capítulo, na análise do passado composto em português. Um estudo pormenorizado é utilizado para comparar este tempo verbal em português em relação a outras línguas românicas. Por meio da descrição de estruturas como "tenho pensado 
nesse assunto", o autor investiga o aspecto verbal neste tipo de perífrase, formada desde o século XVII.

Luisandro Mendes de Souza explora as potencialidades semânticas de sintagmas preposicionados intensificadores, como no caso de "a rodo" e "à beça". Neste trabalho em que se verificam formações desse tipo de locução, o pesquisador aponta um certo percurso de cristalização desses sintagmas de modo a ressaltar o fato de que se formaram por intermédio de gramaticalizações, com vistas à organização gramatical de intensificação.

Como contribuição à terceira parte, Márcio Guimarães aborda o percurso semântico do advérbio "justamente". Em seu artigo, o autor reconstrói o processo de reconfiguração semântica deste advérbio, uma vez que traça uma linha diacrônica, em que o advérbio era apenas um modificador e passa a funcionar como um item de focalização em construções do português brasileiro, como no caso de "o cinema fica justamente em frente à farmácia".

No último capítulo da terceira parte, Albert Wall trata do "singular nu" no português do Brasil. Cláusulas como "ainda ontem eu vi menino jogando bola na rua" têm levantado hipóteses significativas para a interpretação de "menino" nesse tipo de contexto. Na verdade, trata-se de um substantivo com o morfema zero para o plural, mas que, em contexto, pode parecer um coletivo. O autor lança mão de uma série de exemplos para abordar este assunto em perspectiva diacrônica.

Na quarta parte, que encerra as contribuições aos estudos de semântica diacrônica, os autores dão conta do "léxico e construções". Verena Kewitz, Maria Lucia Leitão de Almeida e Janderson Lemos de Souza descrevem preposições e locuções que dão conta da localização espacial. Este estudo sistematiza o processo de gramaticalização 
pelo qual passaram nomes como "cerca, cima e baixo" até virarem locuções de valor espacial e entraram na lista de itens da gramática, cuja configuração sinaliza o produtivo processo da gramaticalização no âmbito das classes fechadas (caso das preposições).

No segundo capítulo da quarta parte, Valdilena Rammé e Teresa Cristina Wachowicz tratam especificamente da rede construcional do verbo "correr". Colocando em xeque os fatores de mudança no âmbito da regência verbal, as autoras utilizam a reanálise como parâmetro para a comprovação de que esta forma verbal assumiu regências relacionadas ao traço semântico da direcionalidade. Este estudo é de suma relevância para a gramática das construções, já que enxerga a potencialidade da gramática na emergência de novos usos linguísticos.

O penúltimo capítulo da obra é de Alessandra Castilho da Costa. Em seu texto, a autora alia o estudo do léxico ao estudo do discurso e utiliza, para tanto, a narrativa bíblica como corpus. Por intermédio da observação de operadores que introduzem a fala de personagens bíblicas, a pesquisadora investe na produtiva interface dos estudos discursivos, considerados em sua localização histórica, e oferece-nos a oportunidade de compreender que o estudo do léxico pode e deve ser fomentado no texto bíblico.

No último capítulo de História semântica do português brasileiro, Laura Álvarez e Juanito Avelar dedicam-se à descrição de verbos de raiz africana. Trata-se de um capítulo de extrema relevância à constituição do repertório lexical no âmbito do português brasileiro, na medida em que os pesquisadores revisitam a questão dos africanismos e, especificamente, abordam peculiaridades do verbo "cuendar". Neste capítulo, fica clara a noção de que há inúmeras influências lexicais do português africano no português brasileiro. 
DOI: $10.12957 /$ palimpsesto.2020.51404

Sem sombra de dúvida, a obra organizada por Rodolfo llari e Renato Basso traz muitas contribuições na esfera dos estudos diacrônicos em língua portuguesa. História semântica do português brasileiro é um livro que, como outros da série, tem uma responsabilidade ímpar, a saber: operar um estudo filológico em torno de unidades da língua que emergem em condições históricas e são, portanto, a prova de que a semântica é/está sensível em relação aos usos linguísticos.

Recebido em 31 de maio de 2020.

Aceito em 31 de maio de 2020. 